\title{
Purification and characterization of glutathione peroxidase 1 in the red muscle of Pacific bluefin tuna Thunnus orientalis
}

\author{
Yumiko Yamashita Takeshi Yabu • \\ Ken Touhata $\cdot$ Michiaki Yamashita
}

Received: 15 October 2011 / Accepted: 9 December 2011/Published online: 18 January 2012

(C) The Author(s) 2012. This article is published with open access at Springerlink.com

\begin{abstract}
Glutathione peroxidase GPx1 was purified from the red muscle of Pacific bluefin tuna Thunnus orientalis and its enzymatic properties were characterized. The enzyme was optimally active at $\mathrm{pH} 7.4$ with a specific activity for hydrogen peroxide and a $K_{\mathrm{m}}$ of $6.7 \mu \mathrm{M}$. cDNA was also isolated and it contained a predicted open reading frame (ORF) encoding a 188 amino acid protein. The phylogenetic tree shows that fish including Pacific bluefin tuna, pufferfish, and zebrafish, but not mammals, possess two genetically distinct types of GPx1, i.e., GPx1a and GPx 1b. The purified enzyme was classified as a fish GPx-1b enzyme on the basis of the phylogenetic tree of the GPx1 family.
\end{abstract}

Keywords Pacific bluefin tuna - Fish - Glutathione peroxidase $\cdot$ Red muscle $\cdot$ Selenium $\cdot$ Selenoprotein

\section{Introduction}

Glutathione peroxidase (GPx, EC1.11.1.9) reduces hydroperoxides, including hydrogen peroxides, in the presence of reduced glutathione as a means of protecting organisms from oxidative damage. Several GPx isozymes have been identified in animal cells and these have been classified into different groups according to their cellular location and substrate specificity. In humans, eight types of GPx have been identified from GPx1 to GPx8 [1]. GPx1, whose preferred substrate is hydrogen peroxide [1], is the most

Y. Yamashita $\cdot$ T. Yabu $\cdot$ K. Touhata $\cdot$ M. Yamashita $(\bowtie)$

National Research Institute of Fisheries Science,

Kanazawa, Yokohama, Kanagawa 236-8648, Japan

e-mail: mic@affrc.go.jp abundant isozyme and is localized in the cytoplasm of animal tissues. GPx1 is a tetramer of identical subunits. Each subunit contains a selenocysteine residue in the active center that facilitates the two-electron reduction of peroxide. Glutathione acts as the electron donor to regenerate the reduced form of the selenocysteine residue.

Selenium is an essential micronutrient for human health [1-3]. Food sources include fish and other seafood, red meat, eggs, chicken, and liver [3]. Selenium is incorporated in selenocysteine residues during protein synthesis to produce antioxidant enzymes such as GPx [4-17], thioredoxin reductase [18], and selenoprotein $P$ [19].

Recently, a novel selenium-containing compound, selenoneine, was identified as the major form of organic selenium in the muscle and other tissues of tuna [20-22]. This compound has a unique selenoketone structure and a strong antioxidant capacity. The dietary intake of selenoneine through the consumption of fish may be important in free radical detoxification mechanisms. In addition, GPx 1 has been identified as a major selenoprotein in tuna muscle [20-22]. Our recent study showed that selenoneine is incorporated into human and fish cells by the organic cation/carnitine transporter OCTN1 where it mediates methylmercury detoxification (Yamashita et al., submitted). Thus, these two selenium compounds, selenoneine and GPx1, may be involved in multiple nutritional pathways and may serve as selenium antioxidants in tuna tissues. Preliminary studies have indicated that selenoneine induces the expression of GPx1 in cultured fish and mammalian cells, suggesting that selenoneine might be used as a selenium source in selenoprotein synthesis. It has been suggested that a selenium-switch controls mRNA stability and helps determine the transcript abundance of GPx1 [1]. In addition, selenium regulation has been identified in selenoprotein translation mechanisms. 
Therefore, there may be a close relationship between selenium redox status and selenoprotein synthesis. It is not known, however, whether the selenoneine that is abundant in fish cells and tissues is used in selenoprotein synthesis. Protein and mRNA levels for several selenoproteins, such as GPx1, are downregulated dramatically by selenium deficiency [23]. GPx1 activities in rat tissues increase with increasing dietary selenium and reach defined plateaus at the selenium requirement [23]. Thus, GPx1 may be a sensitive biomarker for selenium deficiency and redox status in fish.

This report focuses on the molecular characterization and expression of GPx1 in fish. GPx1 was purified and cloned from Pacific bluefin tuna muscle tissue and its biochemical properties were characterized.

\section{Materials and methods}

\section{Materials}

Pacific bluefin tuna Thunnus orientalis (body weight approximately $40 \mathrm{~kg}$ ) was obtained from an aquaculture farm in the Kyushu Islands of Japan and tissues were stored at $-80^{\circ} \mathrm{C}$ until use. Reduced glutathione, hydrogen peroxide, cumene hydroperoxide, and $t$-butyl hydroperoxide were purchased from Wako Pure Chemical (Osaka, Japan). NADPH and glutathione reductase were purchased from Oriental Yeast (Osaka, Japan). A protein calibration kit was purchased from Roche Molecular Biochemicals (Mannheim, Germany).

\section{Enzyme assay}

GPx activity was examined by monitoring the oxidation of NADPH in the presence of GSH reductase, which catalyzes the reduction of oxidized GSH formed by GPx [4]. The activity was measured at $37^{\circ} \mathrm{C}$ in a solution containing $10 \mathrm{mM}$ sodium phosphate buffer ( $\mathrm{pH}$ 7.0), $0.5 \mathrm{mM}$ EDTA, $1 \mathrm{mM}$ sodium azide, $2.5 \mathrm{mM}$ reduced glutathione, $0.25 \mathrm{U} / \mathrm{ml}$ glutathione reductase, and $0.16 \mathrm{mM}$ NADPH. Solution fluorescence was monitored with a spectrofluorophotometer (Hitachi 850, Hitachi) at $460 \mathrm{~nm}$ with an excitation wavelength of $360 \mathrm{~nm}$. Kinetic parameters $K_{\mathrm{m}}$ and $V_{\max }$ were obtained using hydrogen peroxide, cumene hydroperoxide, and $t$-butyl hydroperoxide as substrates at $\mathrm{pH}$ 7.0. Data were analyzed with nonlinear regression of the Michaelis-Menten equation with Prism ver. 5 (GraphPad Software, La Jolla, CA, USA). Protein concentration was determined with Bio-Rad Protein Assay (Bio-Rad Japan, Tokyo, Japan) using bovine serum albumin as a standard. One enzyme unit of GPx activity is defined as $1 \mu \mathrm{mol}$ of $\mathrm{NADPH}$ oxidized per minute at $37^{\circ} \mathrm{C}$.
Purification of GPx1 from tuna red muscle

Red muscle of Pacific bluefin tuna $(600 \mathrm{~g})$ was cut and homogenized with a Polytron homogenizer (Kinematica, Switzerland) in three volumes of $20 \mathrm{mM}$ Tris- $\mathrm{HCl}$ buffer (pH 7.4) containing $1 \mathrm{mM}$ EDTA-2Na and $1 \mathrm{mM}$ GSH. The homogenate was centrifuged at $7000 \times g$ for $30 \mathrm{~min}$ and the supernatant was passed through a DEAE-Sephadex A-50 (Sigma-Aldrich Japan) column $(60 \mathrm{~mm} \times 200 \mathrm{~mm})$ that had been equilibrated in the same buffer described above. Fractions were concentrated with polyethylene glycol-20000 (Wako Pure Chemical Industries, Osaka), dialyzed against the buffer used to equilibrate a DEAESephadex A-50 column, and passed through a second DEAE Sephadex-A50 column $(60 \mathrm{~mm} \times 300 \mathrm{~mm})$. The column was washed with the buffer and the enzymes were eluted with a linear gradient of $\mathrm{NaCl}(0-0.2 \mathrm{M})$. The active fraction was concentrated to $5 \mathrm{ml}$ with an Amicon stirred cell 8050 equipped with a PM-50 membrane (Millipore, Billerica, MA, USA), run through a gel filtration chromatography Hiprep Sephacryl S-200 column $(16 \mathrm{~mm} \times$ $600 \mathrm{~mm}$, Pharmacia, Sweden), and eluted with $10 \mathrm{mM}$ Tris-HCl buffer (pH 6.8) containing $100 \mathrm{mM} \mathrm{NaCl}, 1 \mathrm{mM}$ EDTA-2Na, and $1 \mathrm{mM}$ GSH. Then the active fraction was concentrated with an Amicon stirred cell 8050, equilibrated with $20 \mathrm{mM}$ HEPES buffer (pH 6.8) containing $1 \mathrm{mM}$ EDTA-2Na and $1 \mathrm{mM} \mathrm{GSH}$, purified with a Mono Q column (5 mm $\times 20 \mathrm{~mm}$, Pharmacia), washed with buffer, and eluted with a linear gradient of $\mathrm{NaCl}(0-0.5 \mathrm{M})$.

\section{Isolation of cDNA clones}

The red muscle was lysed in TriZol reagent (Invitrogen, Carlsbad, CA, USA) and the total RNA was harvested by ethanol precipitation according to the manufacturer's instructions. Poly(A) RNA was purified with oligo(dT)resin (Oligotex; Takara Bio, Ohtsu, Japan). Double-stranded cDNA was synthesized using oligo(dT) primers and a cDNA library was prepared using a Rapid Amplification of cDNA Ends kit (Clontech Laboratories, Mountain View, CA, USA). The cDNA fragments encoding GPx1 were amplified with the following PCR primers: $g p x-1$, upstream $5^{\prime}$ - TTT TAC GAS CTG TCC GCA AAR CTM YTG TCA GGA GA $-3^{\prime}$ corresponding to the amino acid sequence FYDLSAKLLSGD of zebrafish GPx-1a, downstream $5^{\prime}$ - TCT TTT ACA TAT TTA TCA RAA WCY CCC CT -3' corresponding to the $3^{\prime}$ noncoding sequence of zebrafish GPx-1a. These were subcloned into the pGEM-T Easy vector (Promega, USA). Two distinct cDNA clones encoding GPx1 were isolated. We synthesized specific PCR primers corresponding to both cDNA clones, namely TunaGpx1A-1a (5'- CTC TCC AAC GGC CAT GAA GTT TAC TTG ACC $\left.-3^{\prime}\right)$ and TunaGpx1B-1a (5'- CGG TCG 
GAC AAC GTT TTG GAT TAG TTT GCC $-3^{\prime}$ ), and amplified $5^{\prime}$ sequences for GPx1a and GPx1b cDNA.

Sequence analysis

Nucleotide sequences were determined with a DNA sequencer (ABI model3100; Perkin Elmer, Waltham, MA, USA) and a BigDye terminator cycle sequencing kit (Perkin Elmer).

\section{Mass spectrometry}

Mass measurements were made after peak smoothing and internal calibration (Quattro II, Micromass, UK). After carboxymethylation of the purified enzyme and digestion with trypsin, the peptide fragments were identified on the basis of the deduced amino acid sequence of the cDNA using electron spray ionization mass spectrometry (ESIMS) according to previously described methods [24].

\section{Western blotting}

Rabbit polyclonal antibodies were raised against the synthetic peptide HQENCKNDEI [amino acid (aa) 71-80] corresponding to the conserved amino acid sequence between rainbow trout GPx1 (AF281338) and Pacific bluefin tuna GPx1s. The obtained antiserum was affinity-purified using a protein G Sepharose column (GE Healthcare Japan, Tokyo, Japan). Sample tissues were homogenized and centrifuged at $10000 \times g$ for $10 \mathrm{~min}$ at $4^{\circ} \mathrm{C}$. The extracted proteins from the tissues were mixed with $1 / 4$ volume of $5 \times$ sample buffer $[0.2 \mathrm{M}$ Tris- $\mathrm{HCl}, \mathrm{pH} 6.8,10 \%$ sodium dodecyl sulfate, $10 \mathrm{mM}$ 2-mercaptoethanol, $20 \%$ glycerol, $0.05 \%$ bromophenol blue, and protease inhibitor cocktail (Roche Diagnostics, Tokyo, Japan)], and heated at $100^{\circ} \mathrm{C}$ for $1 \mathrm{~min}$. Proteins were separated in a $12.5 \%$ gel by SDSPAGE and electroblotted onto a polyvinylidene difluoride membrane (GE Healthcare Japan). Protein bands were visualized using an $\mathrm{ECL}^{\mathrm{TM}}$ Western blotting detection kit (GE Healthcare Japan) and Hybond-ECL film (GE Healthcare Japan) according to the manufacturer's protocol.

\section{Results}

Purification

GPx was purified 565-fold by four stages of gel chromatography on DEAE-Sephadex A-50, Sephacryl S-200, and MonoQ ion exchange columns with an overall yield of $0.8 \%$ (Fig. 1; Table 1). Homogeneity was confirmed by polyacrylamide gel electrophoresis and the molecular mass was estimated to be $22 \mathrm{kDa}$. Using gel filtration on
Sephacryl S-200, we estimated the molecular mass of the complete enzyme to be $90 \mathrm{kDa}$, indicating that the native enzyme is tetramer.

Enzyme activities

The activity of the purified enzyme was characterized. The activity against hydrogen peroxide was optimal at $\mathrm{pH} 7.4$ at
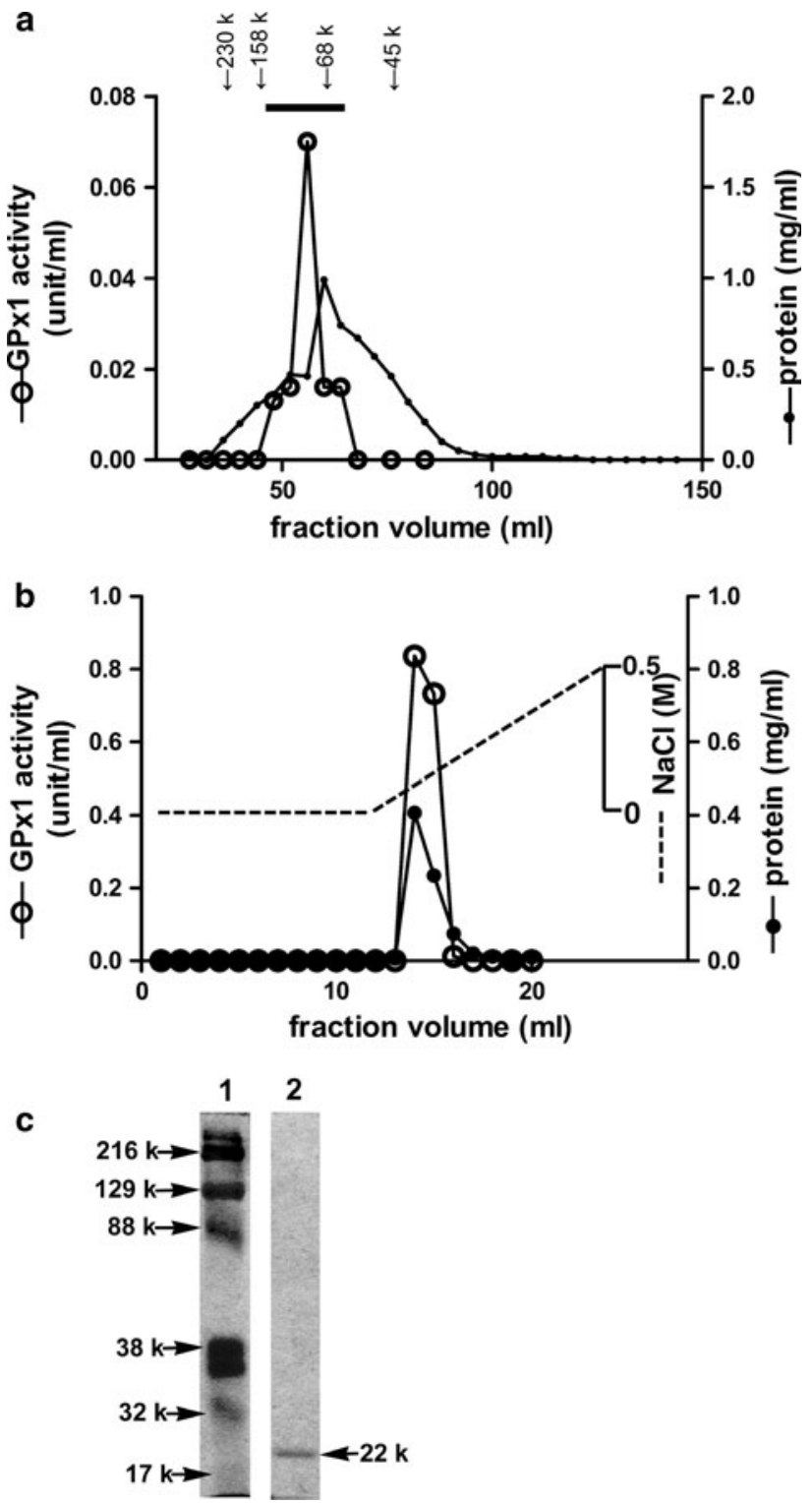

Fig. 1 Purification of GPx1 from the red muscle of Pacific bluefin tuna. a Sephacryl S-200 chromatography. Bar indicates fractions collected for the further purification step. Arrows indicate elution of marker proteins, such as ferritin $(440 \mathrm{kDa})$, catalase $(232 \mathrm{kDa})$, aldolase $(158 \mathrm{kDa})$, serum albumin $(68 \mathrm{kDa})$, and ovalbumin (45 kDa). b monoQ ion exchange chromatography. c SDS-PAGE of purified enzyme. Arrow indicates a $22-\mathrm{kDa}$ protein. SDS-PAGE $(12.5 \%$ gel $)$ was performed after reducing the sample. The gel was stained with Coomassie Brilliant Blue R-250 
$37^{\circ} \mathrm{C} . K_{\mathrm{m}}$ and $V_{\max }$ values were $6.8 \mu \mathrm{M}$ and $1.25 \mathrm{~s}^{-1}$ for hydrogen peroxide, $16.0 \mu \mathrm{M}$ and $0.38 \mathrm{~s}^{-1}$ for cumene hydroperoxide, $7.0 \mu \mathrm{M}$ and $0.71 \mathrm{~s}^{-1}$ for $t$-butyl hydroperoxide. The $K_{\mathrm{m}}$ of the enzyme for glutathione was $1.51 \mathrm{mM}$.

cDNA cloning and expression

We isolated two distinct types of cDNA clones encoding GPx1. (Fig. 2). The selenocysteine residue in the enzymes corresponded to a TGA codon in the coding region of the cDNAs, similar to mammalian GPx1 genes and other selenoproteins. Both cDNA clones that encoded glutathione

Table 1 Purification of glutathione peroxidase from the red muscle of bluefin tuna

\begin{tabular}{llllll}
\hline & $\begin{array}{l}\text { Total } \\
\text { protein } \\
\text { (mg) }\end{array}$ & $\begin{array}{l}\text { Total } \\
\text { activity } \\
\text { (unit) }\end{array}$ & $\begin{array}{l}\text { Specific } \\
\text { activity } \\
\text { (unit/mg) }\end{array}$ & $\begin{array}{l}\text { Purification } \\
\text { (fold) }\end{array}$ & $\begin{array}{l}\text { Yield } \\
(\%)\end{array}$ \\
\hline $\begin{array}{l}\text { 1. Crude } \\
\text { extract }\end{array}$ & 18700 & 56.0 & 0.006 & 1 & 100 \\
$\begin{array}{l}\text { 2. DEAE } \\
\text { Sephadex }\end{array}$ & 1266 & 19.5 & 0.031 & 5 & 35 \\
$\begin{array}{l}\text { A-50 } \\
\text { 3. DEAE }\end{array}$ & 245 & 10.5 & 0.043 & 7 & 9 \\
$\begin{array}{l}\text { Sephadex } \\
\text { A-50 }\end{array}$ & & & & & \\
$\begin{array}{l}\text { 4. Sephacryl } \\
\text { S-200 }\end{array}$ & 79 & 5.3 & 0.067 & 11 & 4.7 \\
$\begin{array}{l}\text { 5. DEAE } \\
\text { Sephadex }\end{array}$ & 20 & 5.3 & 0.067 & 44 & 4.7 \\
A-50 & & & & & \\
$\begin{array}{l}\text { 6. Sephacryl } \\
\text { S-200 }\end{array}$ & 2.3 & 2.2 & 0.94 & 156 & 1.9 \\
\begin{tabular}{l} 
7. Mono Q \\
\hline
\end{tabular} & 0.25 & 0.9 & 3.39 & 565 & 0.8 \\
\hline
\end{tabular}

peroxidase possessed significant homologies with the zebrafish GPx1a and GPx1b [25], and were named Pacific bluefin tuna GPx1a and GPx1b, respectively. The bluefin tuna GPx1a cDNA contained a predicted open reading frame (ORF) encoding a 189 amino acid protein (predicted molecular weight, 21728), whereas GPx 1b cDNA contained a predicted ORF encoding a 188 amino acid protein (predicted molecular weight, 21451) (Fig. 3). They showed conservation of the selenocysteine residue at the active center that was encoded in a TGA codon.

GPx1a shares 88, 78, 73, 73, and 70\% sequence homology with tilapia GPx1, zebrafish GPx1a [25], zebrafish GPx1b [25], southern bluefin tuna GPx1 [26], and bovine GPx1 [15], respectively (Fig. 3). GPx1b shares 97 and $76 \%$ sequence homology with southern bluefin tuna GPx1 [26] and zebrafish GPx1b [25], respectively. The phylogenetic tree of GPx1 in vertebrates shows that fish including Pacific bluefin tuna, zebrafish and Takifugu, but not mammals, possess two genetically distinct types of GPx1, known as GPx1a and GPx1b (Fig. 4).

The purified protein was S-carboxymethylated, and digested with trypsin. ESI-MS analysis of the resulting peptide mixture detected an ion corresponding to the amino acid sequence VVLIVNVASLUGTTTR, $[\mathrm{M}+2 \mathrm{H}]$ $\mathrm{m} / \mathrm{z} 597.54$ (observed), 596.785 (calculated), which contains an S-carboxymethylated selenocysteine residue of bluefin tuna GPx1b. Thus, the purified enzyme was due to GPx $1 b$, and selenocysteine-37 was identified at the active center of the enzyme (Fig. 3). These findings indicate that the purified enzyme consists of four identical subunits of GPx1b.

Thus, fish including Pacific bluefin tuna, Takifugu, and zebrafish, but not mammals, possess two genetically distinct types of GPx1, i.e., GPx1a and GPx1b. Thus, mammals
Fig. 2 Nucleotide sequence and deduced amino acid sequence of Pacific bluefin tuna GPx1. A putative TGA codon encoding a selenocysteine residue is underlined. Selenocysteine insertion sequence (SECIS) in the $3^{\prime}$ noncoding region is boxed

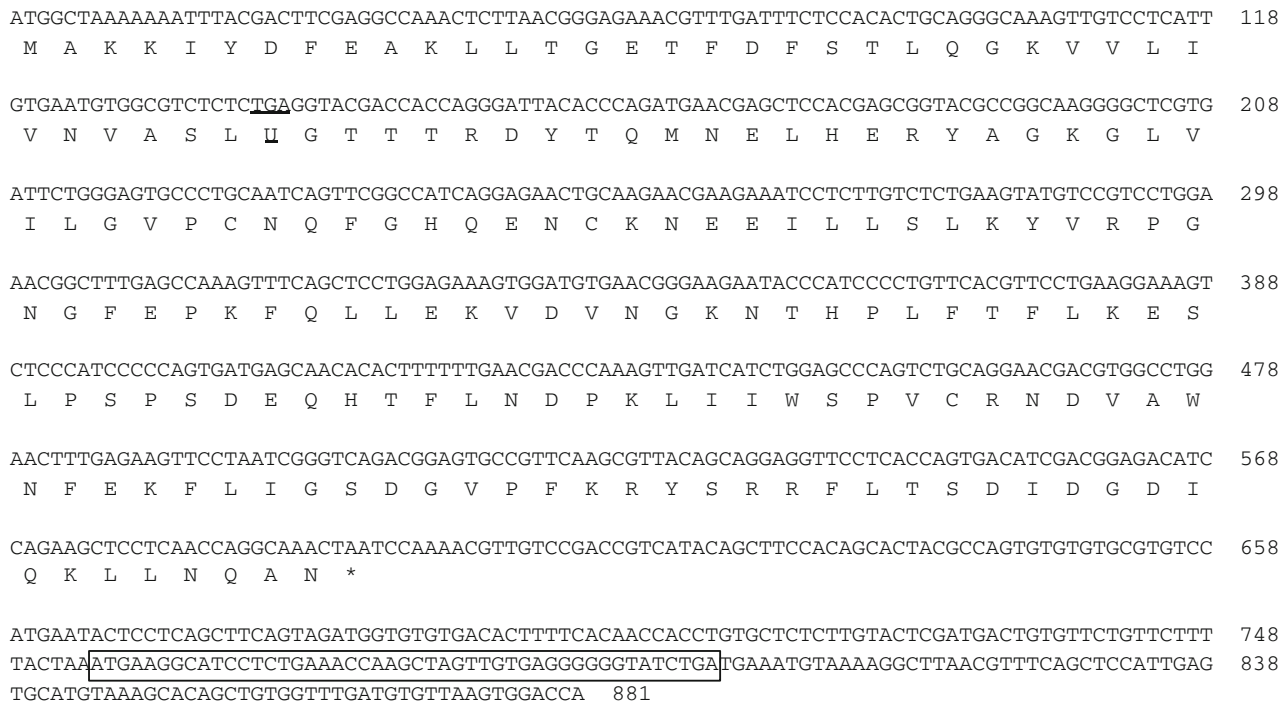

ATGAATACTCCTCAGCTTCAGTAGATGGTGTGTGACACTTTTCACAACCACCTGTGCTCTCTTGTACTCGATGACTGTGTTCTGTTCTTT 748 TACTAA ATGAAGGCATCCTCTGAAACCAAGCTAGTTGTGAGGGGGGTATCTGAIGAAATGTAAAAGGCTTAACGTTTCAGCTCCATTGAG 838 TGCATGTAAAGCACAGCTGTGGTTTGATGTGTTAAGTGGACCA 881 
Fig. 3 Deduced amino acid sequences of Pacific bluefin tuna GPx1a, GPx1b, and bovine GPx1. A putative selenocysteine residue in the active center is boxed

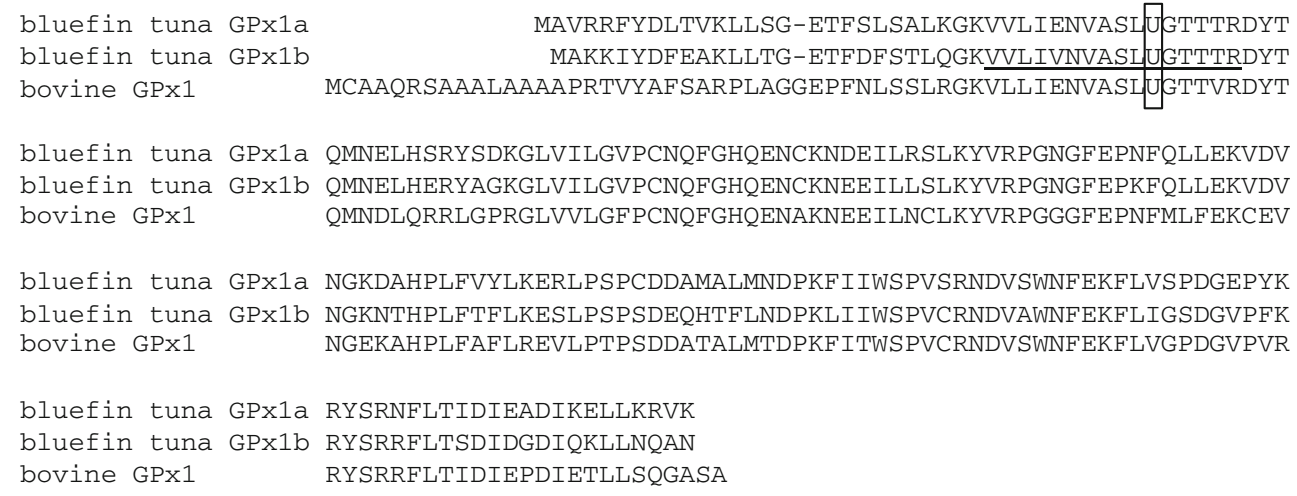

bluefin tuna GPx1a bluefin tuna GPx1b bovine GPx1 MCAAQRSAAALAAAAPRTVYAFSARPLAGGEPFNLSSLRGKVLLIENVASLUGTTVRDYT

bluefin tuna GPX1a QMNELHSRYSDKGLVILGVPCNQFGHQENCKNDEILRSLKYVRPGNGFEPNFQLLEKVDV bluefin tuna GPx1b QMNELHERYAGKGLVILGVPCNQFGHQENCKNEEILLSLKYVRPGNGFEPKFQLLEKVDV bovine GPX1 QMNDLQRRLGPRGLVVLGFPCNQFGHQENAKNEEILNCLKYVRPGGGFEPNFMLFEKCEV

bluefin tuna GPX1a NGKDAHPLFVYLKERLPSPCDDAMALMNDPKFIIWSPVSRNDVSWNFEKFLVSPDGEPYK bluefin tuna GPX1b NGKNTHPLFTFLKESLPSPSDEQHTFLNDPKLIIWSPVCRNDVAWNFEKFLIGSDGVPFK bovine GPX1 NGEKAHPLFAFLREVLPTPSDDATALMTDPKFITWSPVCRNDVSWNFEKFLVGPDGVPVR $\begin{array}{ll}\text { bluefin tuna GPx1a RYSRNFLTIDIEADIKELLKRVK } \\ \text { bluefin tuna GPx1b RYSRRFLTSDIDGDIQKLLNQAN } \\ \text { bovine GPX1 } & \text { RYSRRFLTIDIEPDIETLLSQGASA }\end{array}$

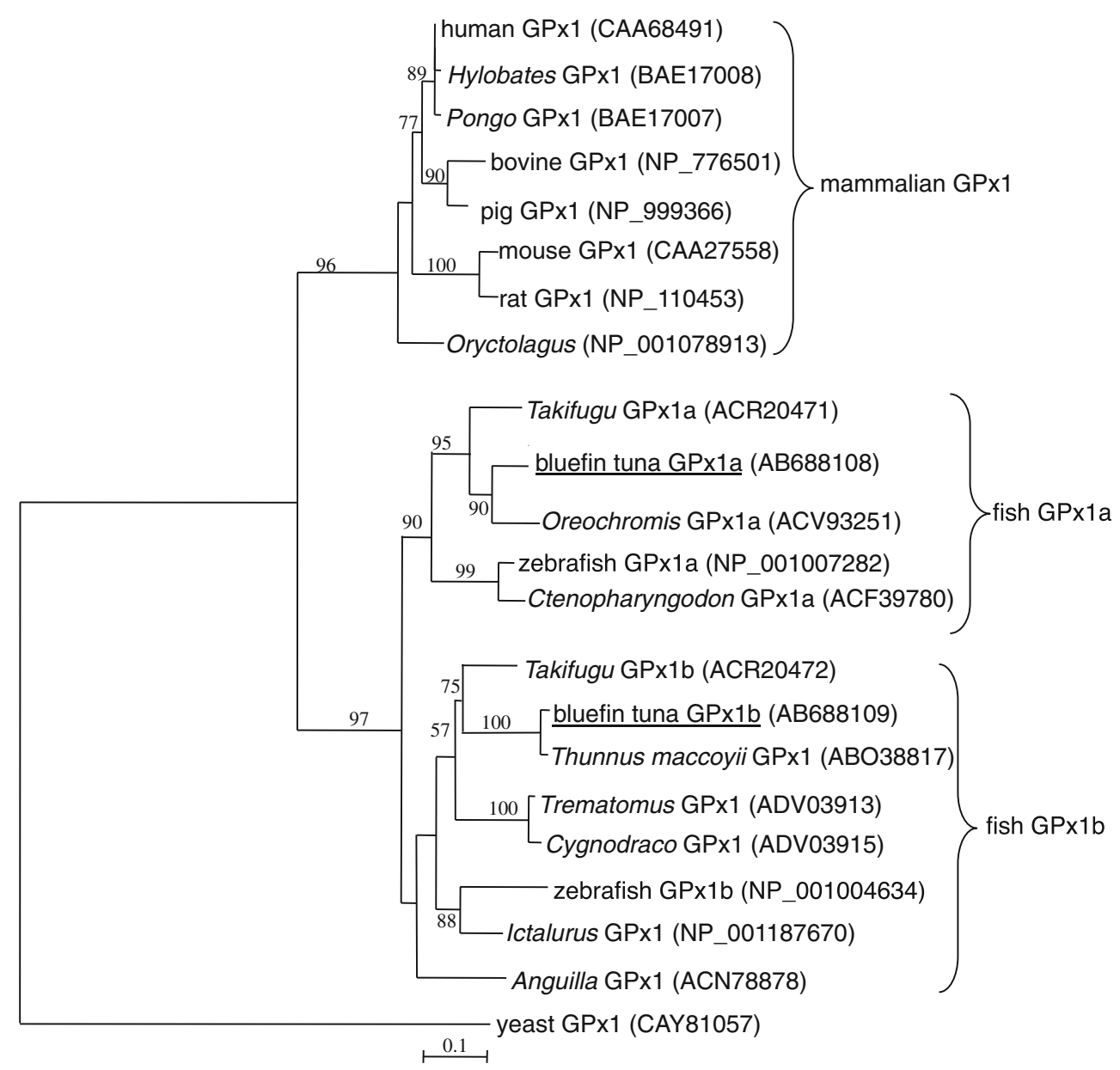

Fig. 4 Phylogenetic relationships among vertebrate GPx1 enzymes. The tree was constructed with a protein maximum likelihood program, PHYML 3.0 [30]. Bootstrap confidence values for the sequence groupings are indicated in the tree $(n=100)$. The Pacific

possess a single copy of GPxl, whereas fish possess two distinct types of GPxl.

Gene synteny analysis showed that zebrafish GPx1b (zgpxlb on zebrafish chromosome 6) was orthologous to human GPx1 (human chromosome 3, p21.31). In contrast, bluefin tuna GPx1a and GPx1b, identified in this study, are underlined. Sequences database accession numbers in DDBJ/ EMBL/GenBank are indicated in parentheses. The scale indicates the evolutionary distance of one amino acid substitution per site

the gene synteny of zebrafish GPx1a (zgpxla on zebrafish chromosome 11) was not comparable to those of human chromosomes. Therefore, the fish GPxla cluster members, including Pacific bluefin tuna GPxla, zebrafish GPxla, and Takifugu GPxla, may be derived from 
duplication of the ancestral GPxl gene during vertebrate evolution.

The selenocysteine insertion sequence (SECIS) is an RNA element of approximately 60 nucleotides that adopts a stem-loop structure and directs the cell to translate UGA codons as selenocysteines. These sequences were present in the $3^{\prime}$-noncoding region of the isolated GPx 1 cDNA clones, indicating that the genes encoding selenoproteins include one or more selenocysteine residues (Fig. 2).

Specific polyclonal antibody was raised against the fish GPx 1 and the expression of GPx1 in several tissues of bluefin tuna was examined by Western blot analysis (Fig. 5). The antibody cross-reacted with the $22-\mathrm{kDa}$ protein band in red muscle (Fig. 5a, lane 1). The staining disappeared completely when the antibody was pre-incubated with the purified GPx1 (Fig. 5a, lane 2), indicating that the antibody is specific to bluefin tuna GPx1. GPx1 expression was detected in red muscle, heart, spleen, and hepatopancreas, but not in white muscle.

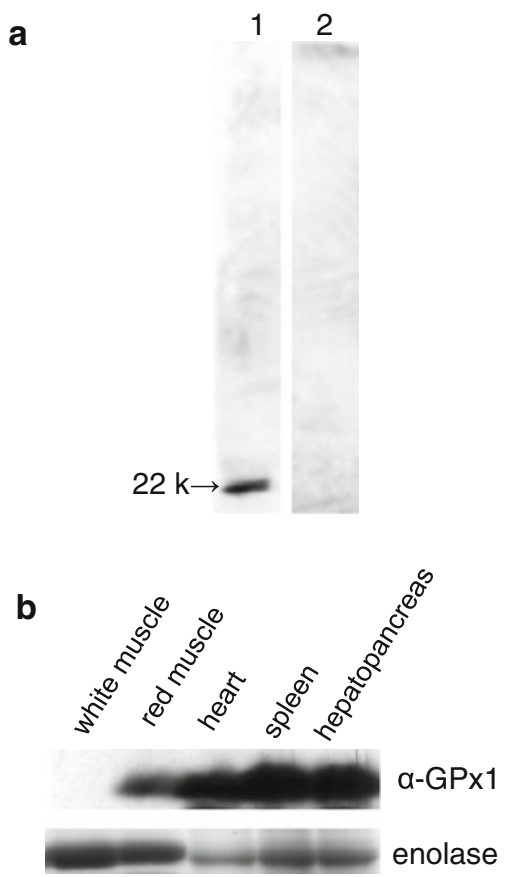

Fig. 5 Expression of GPx1 in various tissues of Pacific bluefin tuna by Western blotting. a Water-soluble proteins (10 $\mu \mathrm{g} / \mathrm{lane})$ in the red muscle were separated in a $12.5 \%$ SDS-PAGE gel. GPx 1 expression was detected by Western blotting using an anti-GPx1 antibody (lane 1). The arrow indicates a $22-\mathrm{kDa}$ protein. The staining disappeared completely when the antibody (20 ng of $\mathrm{IgG})$ was preincubated with the purified tuna GPx1 $(0.5 \mu \mathrm{g})$ to remove the crossreactive antibodies (lane 2$)$. b Water-soluble proteins $(17 \mu \mathrm{g} / \mathrm{lane})$ in the white muscle, red muscle, heart, spleen, and hepatopancreas were separated in a $12.5 \%$ SDS-PAGE gel. GPx 1 was detected by immunostaining with anti-GPx1 antibody, and enolase was detected as an internal control by Coomassie Brilliant Blue R-250 staining

\section{Discussion}

GPx1 was purified from the red muscle of Pacific bluefin tuna. The enzyme has a molecular weight of 90000 and consists of four identical $22-\mathrm{kDa}$ subunits. The enzyme exhibited a broad substrate specificity against hydrogen peroxide with an optimal activity at $\mathrm{pH} 7.4$ as well as organic hydroperoxides like cumene hydroperoxide and $t$-butyl hydroperoxide. $K_{\mathrm{m}}$ and $V_{\max }$ values were $6.8 \mu \mathrm{M}$ and $1.25 \mathrm{~s}^{-1}$ for hydrogen peroxide. The $K_{\mathrm{m}}$ value for hydrogen peroxide was lower than that of other known GPx1s: $83.3 \mu \mathrm{M}$ for human liver GPx1 [27], 12.4 $\mu \mathrm{M}$ for southern bluefin tuna liver GPx1 [16], and $10 \mu \mathrm{M}$ for rainbow trout liver GPx1 [17]. We also found that $K_{\mathrm{m}}$ values of Pacific bluefin tuna GPx1 for cumene hydroperoxide and $t$-butyl hydroperoxide were 16.0 and $7.0 \mu \mathrm{M}$, respectively. These values were lower than those for human GPx1 $(27.8 \mu \mathrm{M}$ for cumene hydroperoxide and $33.3 \mu \mathrm{M}$ for $t$-butyl hydroperoxide) [27], southern bluefin tuna GPx1 (90 $\mu \mathrm{M}$ for cumene hydroperoxide and $90 \mu \mathrm{M}$ for $t$-butyl hydroperoxide) [16], and rainbow trout GPx1 (48 $\mu \mathrm{M}$ for cumene hydroperoxide and $3000 \mu \mathrm{M}$ for $t$-butyl hydroperoxide) [17]. These properties indicate that the purified enzyme is GPx 1 .

To examine its amino acid sequence and expression in vivo, cDNA clones encoding GPx1 were isolated. Two genetically distinct types of GPx1 have been successfully isolated, GPx1a and GPx1b. The GPx1 enzyme purified from the red muscle of tuna in the present study was identified as GPx1b on the basis of its amino acid sequence determined using mass spectrometry of trypsin digests.

In addition, SECIS is required for the incorporation of selenocysteine in selenoprotein synthesis. The nucleotide sequence of SECIS of GPx1 was well conserved in Pacific bluefin tuna.

Phylogenetic analysis of GPx1 among the known vertebrate GPx1 amino acid sequences (Fig. 4) indicated that mammals possess only a single copy of GPxl, whereas fish possess two distinct types of GPx1. Mapping of the zebrafish hox clusters showed that zebrafish has two copies of many human chromosome segments [28]. Postlethwait et al. [29] compared zebrafish genome organization with that of humans and found that large chromosome segments have been conserved for the 430 million years since the divergence of human and zebrafish lineages. At least four copies of some paralogous chromosome segments exist in zebrafish, and they generally correspond to orthologous chromosome segments in mammals, suggesting that whole genome duplication events occurred prior to the divergence of fish and mammal lineages. Thus, the fish GPxla group may arise from the fish GPxlb group through an ancient chromosomal duplication event. Further study is required to characterize the transcriptional and translational regulation 
mechanisms of these two GPx 1 isozymes in fish in response to selenium exposure.

GPX1 is a major selenoprotein, and selenoneine is a low molecular weight compound that acts as a strong free radical scavenger in the red muscle of bluefin tuna [20-22]. These two organic selenium species may be important members of the redox cycle in a variety of physiological and nutritional processes in fish muscle [20, 21].

Acknowledgments This work was supported in part by grants from the Japan Society for the Promotion of Science and the Fisheries Research Agency.

Open Access This article is distributed under the terms of the Creative Commons Attribution Noncommercial License which permits any noncommercial use, distribution, and reproduction in any medium, provided the original author(s) and source are credited.

\section{References}

1. Hatfield DL, Berry MJ, Gladyshev VN (2006) Selenium: its molecular biology and role in human health, 2nd edn. Springer, New York, pp 1-419

2. Mills GC (1957) Hemoglobin catabolism. I. Glutathione peroxidase, an erythrocyte enzyme which protects hemoglobin from oxidative breakdown. J Biol Chem 229:189-197

3. Combs GF Jr (2001) Impact of selenium and cancer-prevention findings on the nutrition-health paradigm. Nutr Cancer 40:6-11

4. Rotruck JT, Pope AL, Ganther HE, Swanson AB, Hafeman DG, Hoekstra WG (1972) Selenium: biochemical role as a component of glutathione peroxidase. Science 179:588-590

5. Mills GC (1958) The purification and properties of glutathione peroxidase of erythrocytes. J Biol Chem 234:502-506

6. Awasthi YC, Beutler E, Srivastava SK (1975) Purification and properties of human erythrocyte glutathione peroxidase. J Biol Chem 250:5144-5149

7. Bagnyukova TV, Storey KB, Lushchak VI (2005) Adaptive response of antioxidant enzymes to catalase inhibition by aminotriazole in goldfish liver and kidney. Comp Biochem Physiol B142:335-341

8. Braddon SA, McIlvaine CM, Balthrop JE (1985) Distribution of GSH and GSH cycle enzymes in black sea bass (Centropristis striata). Comp Biochem Physiol B80:213-216

9. Kai N, Tsuda T, Sakai T, Murata H, Hamada M, Tanoue Y, Nagai $\mathrm{T}$ (1995) Glutathione peroxidase activity in the blood of tunas and marlins. Fish Sci 61:867-870

10. Kolayi S, Arikan M, Uzunosmanoglu D, Vanizor B, Kiran E, Sagban R (1997) Comparative studies on antioxidant enzyme activities and lipid peroxidation in different fish species. Tr J Zool 21:171-173

11. Nagai T, Yukimoto T, Suzuki N (2002) Glutathione peroxidase from the liver of Japanese sea bass Lateolabrax japonicus. Z Naturforsch 57c:172-176

12. Nakano T, Sato M, Takeuchi M (1992) Glutathione peroxidase of fish. J Food Sci 57:1116-1119
13. Perez-Campo R, Lopez-Torres M, Rojas C, Cadenas S, Barja G (1993) A comparative study of free radicals in vertebrates-I. Antioxidant enzymes. Comp Biochem Physiol B105:749-755

14. Watanabe F, Goto M, Abe K, Nakano Y (1996) Glutathione peroxidase activity during storage of fish muscle. J Food Sci 61:734-735

15. Carmagnol F, Sinet PM, Jerome H (1983) Selenium-dependent and nonselenium-dependent glutathione peroxidases in human tissue extracts. Biochim Biophys Acta 759:49-57

16. Thompson JL, Thomas PM, Schuller KA (2006) Purification and properties of a glutathione peroxidase from Southern bluefin tuna (Thunnus maccoyii) liver. Comp Biochem Physiol B144:86-93

17. Bell JG, Cowey CB, Youngson A (1984) Rainbow trout liver microsomal lipid peroxidation. The effect of purified glutathione peroxidase, glutathione S-transferase and other factors. Biochim Biophys Acta 795:91-99

18. Mustacich D, Powis G (2000) Thioredoxin reductase. Biochem J 346 Pt 1:1-8

19. Burk RF, Hill KE (1994) Selenoprotein P. A selenium-rich extracellular glycoprotein. J Nutr 124:1891-1897

20. Yamashita Y, Yamashita M (2010) Identification of a novel selenium-containing compound, selenoneine, as the predominant chemical form of organic selenium in the blood of bluefin tuna. J Biol Chem 285:18134-18138

21. Yamashita Y, Yabu T, Yamashita M (2010) Discovery of the strong antioxidant selenoneine in tuna and selenium redox metabolism. World J Biol Chem 1:144-150

22. Yamashita Y, Amlund H, Suzuki T, Hara T, Hossain MA, Yabu T, Touhata K, Yamashita M (2011) Selenoneine, total selenium, and total mercury content in the muscle of fishes. Fish Sci 77:679-686

23. Raines AM, Sunde RA (2011) Selenium toxicity but not deficient or supernutritional selenium status vastly alters the transcriptome in rodents. BMC Genomics 12:26-40

24. Thongboonkerd V, Luengpailin J, Cao J, Pierce WM, Cai J, Klein JB, Doyle RJ (2002) Fluoride exposure attenuates expression of Streptococcus pyogenes virulence factors. J Biol Chem 277:16599-16605

25. Kryukov GV, Gladyshev VN (2000) Selenium metabolism in zebrafish: multiplicity of selenoprotein genes and expression of a protein containing 17 selenocysteine residues. Genes Cells 5:1049-1060

26. Thompson JL, See VHL, Thomas PM, Schuller KA (2010) Cloning and characterization of two glutathione peroxidase cDNAs from southern bluefin tuna (Thunnus maccoyii). Comp Biochem Physiol B156:287-297

27. Miwa T, Adachi T, Ito Y, Hirano K (1983) Purification and properties of glutathione peroxidase from human liver. Chem Pharm Bull 31:179-185

28. Amores A, Force A, Yan Y-L, Joly L, Amemiya C, Fritz A, Ho RK, Langeland J, Prince V, Wang Y-L (1998) Zebrafish hox clusters and vertebrate genome evolution. Science 282:1711-1714

29. Postlethwait J, Yan Y, Gates M, Horne S, Amores A, Brownlie A, Donovan A, Egan E, Force A, Gong Z (1998) Vertebrate genome evolution and the zebrafish gene map. Nat Genet 18:345-349

30. Guindon S, Gascuel O (2003) A simple, fast and accurate algorithm to estimate large phylogenies by maximum likelihood. Syst Biol 52:696-704 